\title{
Disruption of passive avoidance learning by magnesium pemoline'
}

EDWARD M, GUROWITZ, JOEL F. LUBAR, BRENT R. AIN AND DAVID A. GROSS

UNIVERSITY OF ROCHESTER

Magnesium pemoline, a central nervous stimulant which may affect brain RNA production, produces a deficit in passive avoidance behavior. The main effect of the drug appears to be stimulation, with no effect on learning.

Experiments over the past four years have implicated RNA in learning and memory, although contradictory results have appeared (see Gaito, 1966; Byrne et al, 1966). Glasky \& Simon (1966) reported that magnesium pemoline, a mild central nervous system stimulant, augments brain RNA polymerase, which is presumed to facilitate endogenous RNA production. At the same time, Plotnikoff (1966) reported facilitation of an active avoidance response (pole climbing) by this drug.

Since these initial reports were published, a body of negative evidence has accrued. Talland (1966) reported improvement of performance on a continuous attention task, interpreting these findings as evidence for an alerting or stimulating effect of the drug. Cyert et al (1966) using, like Plotnikoff, a one-way avoidance response, reported no effect on either rate of learning or of extinction. Working with human Ss, Smith (1967) found no facilitation of learning or memory. Lubar et al (1967) reported an increase in running speed with no simple effect on error scores in the Hebb-Williams maze, again indicating a stimulant effect. Finally, Morris et al (1967) reported that magnesium pemoline has no effect on the concentration or activity of brain RNA in vivo.

The purpose of the present experiment was to employ a task which would pit any effect the drug might have on learning against its stimulant effect. For this purpose, the passive-avoidance response (PAR) seems ideally suited, since while a learning effect would be evidenced as a lack of responding, a stimulant effect, leading to hyperactivity, would cause increased responding.

Method

Ss were 40 male, Holtzman, Sprague-Dawley rats. All animals were 101 or 102 days old at the time of testing. Weights ranged from 279 to $349 \mathrm{gm}$.

The apparatus used consisted of a box, 23 in. $x$ 11-1/2 in. $x 20$ in., with plywood sides, a copper sheet floor, and a cardboard cover. At one end there was a Plexiglas door through which $S$ could be inserted and removed, to the left of which was a removable water dish ( 20 cc capacity) containing a copper electrode. The electrode and floor were con- nected to a shock circuit so that whenever the $S$ drank from the dish, it received a $.83 \mathrm{~mA}$ constant current dc shock with each lick. The number of shocked consummatory responses was recordedgraphically on a Beckman Type RP dynograph.

One week before the experiment, all Ss were placed on a $23 \mathrm{hr}$. water deprivation schedule, with food available ad lib. After five days on this schedule, water was withheld for $48 \mathrm{hr}$. prior to beginning testing. On the test day, each $S$ was placed in the box for $15 \mathrm{~min}$. without the water dish, to adapt it to the situation. Then the $S$ was removed, the water dish placed in the box, and the shock turned on. The $S$ was then returned to the box, and allowed free access to the water for $15 \mathrm{~min}$. Thirty min. prior to the initiation of the shock, each $S$ was injected IP with $1 \mathrm{cc} / 250 \mathrm{gm}$ body weight of either a $5 \mathrm{mg} / \mathrm{cc}$ suspension of magnesium pemoline in a $0.3 \%$ gum tragacanth solution or of the gum tragacanth solution (placebo) alone. Each E tested $10 \mathrm{Ss}$; five drug and five placebo.

Records were scored by one of the Es, without knowledge of the group membership of the Ss. A response was scored as any deflection of the dynograph pen $5 \mathrm{~mm}$ or more, with the gain set at $50 \mathrm{~V} / \mathrm{cm}$. A time marker indicated 1 sec. intervals.

\section{Results}

Because most of the responses occurred early in the test session for both groups, data were scored for the first $\mathrm{min}$. in $15 \mathrm{sec}$. intervals, for the next $4 \mathrm{~min}$. in $1 \mathrm{~min}$. intervals, and for the remaining time in two $5 \mathrm{~min}$. periods. These data are represented graphically in Fig. 1, which shows the cumulated mean numbers of responses for each group. It is clear from this figure that while placebo Ss quickly learned to avoid the water dish, drug Ss continued to receive shocks, even after 10 to $15 \mathrm{~min}$. On the average, drug Ss took 102.65 shocks for the $15 \mathrm{~min}$. period, vs. 59.40 for placebo Ss. This difference was statistically significant $(t=12.98, d f=38$, $\mathrm{p}<.01)$.

\section{Diseussion}

Inspection of Fig. 1 clearly shows that while drug animals took many more shocks than placebo animals, they did show a decrease over time. In general, it appears that they are learning the PAR more poorly than the placebo Ss. This seems to mitigate strongly for a stimulant or motor disinhibition interpretation of these data. That is, even though drug So have 


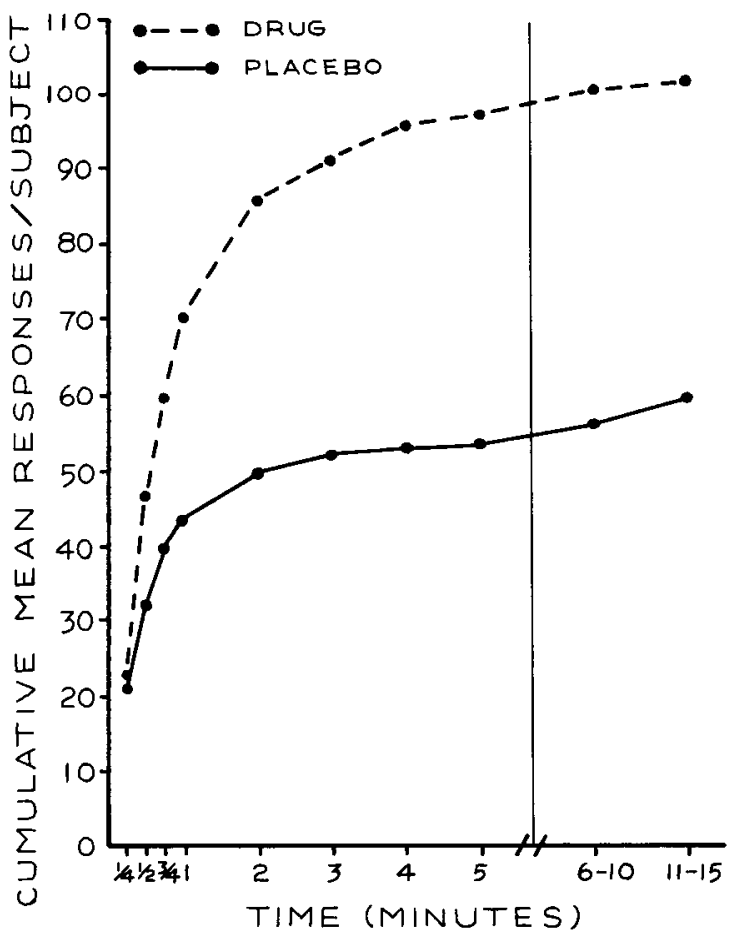

Fig. 1. Cumulated mean responses over time for each group.

learned to avoid the shock, they are unable to withhold responses, presumably due to drug-induced hyperactivity. This is in accord with the data of Gurowitz \& Lubar (1966) indicating that, in cats, lesion-induced hyperactivity is also correlated with a PAR deficit. In general, it would appear that any treatment which moderately increases activity is detrimental to PAR performance.

The data do not support the hypothesis that magnesium pemoline improves learning. In the light of the earlier findings reviewed above, our data lend additional support to the view that the effects of this drug on performance are due to its action as a central stimulant.

One possibility left open by this study, as well as by our previous one (Lubar et al, 1967) is that the drug Ss are more motivated for water than the placebo Ss. This seems unlikely, however, since observation of animals in our previous study that received the drug daily for 12 days did not indicate any large differences in water consumption.

In general, on the basis of these and earlier findings, it seems reasonable to conclude that magnesium pemoline is a central stimulant, affecting performance but not learning.

\section{References}

Byme, W. L. et al. Memory transfer. Science, 1966, 153, 658-659. Cyert, L. A., Moyer, K. E., \& Chapman, J. A. Effect of magnesium pemoline on learning and memory of a one-way avoidance response. Psychon. Sci., 1967, 7, 9-10.

Gaito, J. Macromolecules and behavior. New York: Appleton, 1966. Glasky, A. J., \& Simon, L. N. Magnesium pemoline: enhancement of brain RNA polymerases. Science, 1966, 151, 702-703.

Gurowitz, E. M., \& Lubar, J. F. Changes in activity, food ingestion, and passive avoidance behavior following limbic-septal ablation in the cat. Proc. 74th Annu. Conv. Amer. Psychol. Assoc., 1966, 2, 107-108.

Lubar, J. F., Boitano, J. J., Gurowitz, E. M., \& Ain, B. R. Enhancement of performance in the Hebb-Williams maze by magnesium pemoline. Psychon. Sci., 1967, in press.

Morris, N. R., Aghajanian, G. K., \& Bloom, F. E. Magnesium pemoline: failure to affect in vivo synthesis of brain RNA. Science, $1967,155,1125-1126$.

Plotnikoff, N. Magnesium pemoline: enhancement of learning and memory of a conditioned avoidance response. Science, 1966, 151, 703-704.

Smith, R. G. Magnesium pemoline: lack of facilitation in human learning, memory, and performance tests. Science, 1967, 155, 603-605.

Talland, G. A. Improvement of sustained attention with Cylert. Psychon. Sci., 1966, 6, 493-494.

\section{Note}

1. We are indebted to Abbott Laboratories for their generous donation of the magnesium pemoline. 